Barbara Panciszko

Uniwersytet Wroctawski

DOI: $10.19195 / 2450-274 X .3 .8$

\title{
Postawa rolników z powiatu bolesławieckiego wobec środowiska przyrodniczego
}

Abstrakt: Celem opracowania jest zaprezentowanie wyników badań na temat postaw rolników z powiatu bolesławieckiego wobec środowiska naturalnego. W artykule scharakteryzowane zostało rolnictwo i walory przyrodnicze we wskazanym subregionie. Następnie przedstawiono wyniki ankiety przeprowadzonej wśród rolników, która miała na celu określenie, w jakim stopniu czują się oni odpowiedzialni za stan środowiska przyrodniczego, czy podejmują działania na rzecz jego ochrony oraz czy oczekują za nie wynagrodzenia. Dodatkowo zaprezentowano zróżnicowanie opinii dotyczących wskazanych kwestii w zależności o wieku badanego oraz wielkości posiadanego przez niego gospodarstwa rolnego.

Słowa kluczowe: powiat bolesławiecki, rolnictwo, ochrona środowiska

\section{Attitude of farmers from Bolesławiec County towards the natural environment}

Abstract: The purpose of the study is to present the results of the survey among farmers in district of Bolesławiec. Its purpose was to examine the attitudes of farmers to the environment. Agriculture in the specified subregion was characterized and then there was presented its natural beauty. Subsequently there were presented the results of a survey of farmers, which had to determine whether they feel responsible for the state of the natural environment, and take action on its behalf, or whether there are waiting for compensation. There was indicated diversity of opinions among the three age categories, depending also on the size of the farm.

Keywords: district of Bolesławiec agriculture, protection of the environment by farmers 


\section{Wstęp}

Okres od drugiej połowy XX w. do początku XXI w. charakteryzuje się wysokim poziomem rozwoju technologicznego we wszystkich dziedzinach działalności ludzkiej. Nie ominął on również rolnictwa - sfery gospodarki wytwarzającej podstawowe produkty umożliwiające człowiekowi egzystencję. Postępująca mechanizacja, zastosowanie coraz to nowszych środków ochrony roślin, konieczność zwiększania wydajności czy przeznaczanie na cele rolnicze kolejnych obszarów sprawiają, że działalność tego sektora powoduje nieodwracalne zmiany w środowisku naturalnym, doprowadzając do jego degradacji. Dlatego od postawy rolników, ludzi obecnych w całym łańcuchu produkcyjno-przetwórczym żywności, czyli osób znajdujących się najbliżej środowiska naturalnego, zależy jego stan. Niniejszy artykuł jest próbą zbadania tej postawy w wybranym przez autorkę powiecie.

\section{Rolnictwo w powiecie bolesławieckim}

Powiat bolesławiecki przywrócono na mocy reformy administracyjnej w 1999 r. Jego siedziba znajduje się w Bolesławcu. Położony jest w południowo-zachodniej części kraju, w granicach administracyjnych województwa dolnośląskiego, w jego północno-zachodniej części. W jego obrębie leży 6 gmin: 1 gmina miejska (miasto Bolesławiec) oraz 5 gmin wiejskich (gmina Bolesławiec, gmina Nowogrodziec, gmina Osiecznica, gmina Warta Bolesławiecka, i gmina Gromadka). Jest to obszar o dużej lesistości - aż 50\% obszaru zajmują lasy ${ }^{1}$, a powierzchnia użytków rolnych waha się od ok. 40\% w gminach Osiecznica i Gromadka do ponad $65 \%$ w gminie Warta Bolesławiecka ${ }^{2}$.

Według danych Powszechnego Spisu Rolnego z 2010 r. w powiecie bolesławieckim funkcjonuje 4731 gospodarstw rolnych, z czego powierzchnia $1795 \mathrm{z}$ nich wynosi poniżej 1 ha. Niespełna 80\% gospodarstw widniejących w rejestrze (3728) prowadzi działalność rolniczą. Na wykresie 1 zaprezentowane zostały dane dotyczące liczby gospodarstw w zależności od powierzchni, z uwzględnieniem tych prowadzących działalność rolniczą.

1 Mapa gmin i opis powiatu, 1 marca 2012, http://powiatboleslawiecki.pl/gmina.html (dostęp: 10 lutego 2017).

2 Statystyczne Vademecum Samorząowca, 2017, http://www.stat.gov.pl/vademecum/vademecum_dolnoslaskie/portrety_powiatow/powiat_boleslawiecki.pdf (dostęp: 23 kwietnia 2017). 


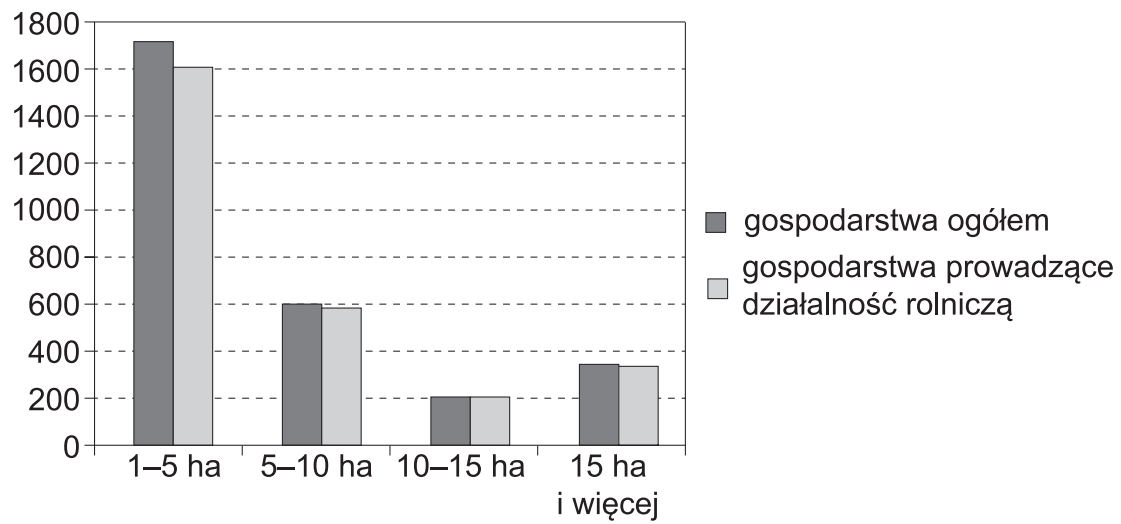

Wykres 1. Liczba gospodarstw rolnych w powiecie bolesławieckim w $2010 \mathrm{r}$.

Źródło: opracowanie własne na podstawie danych GUS.

Z danych zamieszczonych na wykresie można wywnioskować, iż najwięcej gospodarstw rolnych $w$ powiecie bolesławieckim ma powierzchnię w przedziale $1-5$ ha - 1763, z czego 1653 prowadzi działalność rolniczą. Posiadacze gospodarstw powyżej 5 ha w przeważającej mierze prowadzą działalność: 599 na 613 funkcjonujących o powierzchni w przedziale 5-10 ha, wszystkie (211) o powierzchni 10-15 ha oraz 347 na 350 o powierzchni 15 ha i więcej. Należy podkreślić, że w omawianej jednostce samorządu terytorialnego struktura gospodarstw rolnych jest niekorzystna. Dominują małe, niskotowarowe gospodarstwa o powierzchni do 5 ha, które dodatkowo wytwarzają produkty tylko na własny użytek (aż 1075 z 1653) $)^{3}$. Tacy producenci stanowią ok. 35\% wszystkich rolników w powiecie bolesławieckim.

W omawianym subregionie użytki rolne stanowią ok. $90 \%$ powierzchni gospodarstw rolnych ${ }^{4}$. Pod zasiewy wykorzystuje się od 70 do $80 \%$ powierzchni gospodarstw, natomiast łąki i pastwiska stanowią od 0,5 do $1,9 \%^{5}$. Od 18 do 25 tys. ha zajmuje uprawa zbóż; powiat dominuje w województwie dolnośląskim pod względem produkcji żyta i owsa ${ }^{6}$.

\section{Walory przyrodnicze powiatu}

Środowisko przyrodnicze stanowi pokaźny zasób naturalny powiatu. Teren powiatu bolesławieckiego to obszar bardzo cenny przyrodniczo. Znaczną jego część pokrywają lasy będące częścią Borów Dolnośląskich (zajmujących powierzchnię

3 Bank Danych Lokalnych, https://bdl.stat.gov.pl/BDL/dane/teryt/tablica (dostęp: 10 lutego 2017).

4 Główny Urząd Statystyczny, Charakterystyka gospodarstw rolnych $w$ województwie dolnoślaskim - Powszechny Spis Rolny 2010, Warszawa 2012, s. 46.

5 Ibidem, s. 47-48.

6 Ibidem, s. 52. 
$1650 \mathrm{~km}^{2}$ ). Są one jednym z największych kompleksów leśnych w Europie Środkowej. Przeważa tam sosna zwyczajna, czasami można spotkać też dęby lub brzozy. $\mathrm{W}$ niższych partiach leśnych rosną jałowce, jednak lasy te $\mathrm{z}$ reguły są „prześwietlone". Bardzo upodobały sobie to środowisko ciepłolubne trawy, paprocie, wrzosy, jagoda czarna, borówka, mszaki, porosty oraz grzyby.

Obok bogatego świata flory występują również liczni przedstawiciele świata fauny (zające, jelenie, sarny, dziki, lisy). Grono mniejszych ssaków reprezentowane jest przez rude i czarne wiewiórki, ryjówki, jeże i chomiki europejskie ${ }^{7}$. Na tym terenie występuje ok. 150 gatunków ptaków (często zagrożonych wymarciem), m.in. bielik, puchacz, dudek, kania rdzawa i czarna, włochatka, cietrzew, głuszec. Swoje siedliska w Borach Dolnośląskich mają również gatunki wodno-błotne (gęś gęgawa, czapla siwa, łabędź krzykliwy, żuraw, bąk, zimorodek) oraz ptaki drapieżne (krogulec, jastrząb, bielik, trzmielojad, błotniak stawowy). Do tego należy dodać wiele gatunków ryb: lipienie, pstrągi potokowe, brzany, węgorze, okonie czy karasie ${ }^{8}$.

Około 12 tys. ha, czyli $9 \%$ powierzchni powiatu, podlega ochronie prawnej. Obejmują one: zlokalizowany w gminie Bolesławiec rezerwat florystyczny „Brzeźnik”, bór bagienny oraz torfowisko przejściowe w gminie Gromadka (rezerwat leśny „Torfowisko Borówki” i Przemkowski Park Krajobrazowy). W gminie Warta Bolesławiecka 600 ha zajmuje „Wzgórze Grodziec” — obszar chroniony ze względu na pozostałości trzeciorzędowego wulkanizmu. Z kolei gmina Osiecznica może poszczycić się występowaniem na jej terenie „Świętego Jeziora” - zajmującego 153 ha użytku ekologicznego. Do tego należy dodać 230 zabytków przyrody ożywionej i nieożywionej zlokalizowanych na terenie całego powiatu ${ }^{9}$.

W granicach administracyjnych powiatu bolesławieckiego wyznaczane zostały również Obszary NATURA 2000. W Borach Dolnośląskich lęgi odbywają bowiem 32 gatunki ptaków wymienionych w załączniku do Dyrektywy Ptasiej; ulokowane są tu także fragmenty „Doliny Dolnej Kwisy” i „Wrzosowisk Świętoszowsko-Ławszowskich".

Nie należy zapominać o zbiornikach wodnych i rzekach będących kolejnymi cennymi walorami przyrodniczymi. Główne rzeki to: Kwisa, Bóbr z Bobrzycą oraz Czarna Wielka. Niestety na skutek różnego rodzaju zanieczyszczeń, głównie komunalnych, tracą one I klasę czystości ${ }^{10}$.

Bogactwo walorów przyrodniczych znajdujących się na terenie powiatu bolesławieckiego skłania autorkę do stwierdzenia, że należy podjąć wszelkie kroki mające na celu zachowanie ich obecnego stanu.

7 Karkonoska Agencja Rozwoju Regionalnego S.A., Koncepcja subregionalnego produktu turystycznego Borów Dolnośląskich, Jelenia Góra 2009.

8 Ibidem, s. 14-15.

9 Ibidem, s. 16-19.

10 Ibidem, s. 12. 


\section{Znaczenie środowiska naturalnego dla rolników powiatu bolesławieckiego}

Rolnictwo stanowi źródło znacznej części zanieczyszczeń przenoszonych do środowiska. Od postawy i świadomości rolników będzie zatem zależało, jakie działania prewencyjne i naprawcze będą podejmowane. Autorka przeprowadziła ankietę wśród rolników powiatu bolesławieckiego, której celem było pozyskanie informacji odnośnie do tego, jakie mają oni opinie na temat związku działalności rolniczej ze stanem środowiska naturalnego oraz czy i jakie działania podejmują na jego rzecz. Interesujący okazał się również stosunek do płacenia prowadzącym działalność rolniczą za aktywność mającą pozytywny wpływ na środowisko przyrodnicze. Celem ankiety było uzyskanie danych na temat stosunku rolników co do wskazanych kwestii oraz odpowiedź na pytanie dotyczące relacji między opiniami, wielkością posiadanych przez nich gospodarstw rolnych oraz wiekiem.

Przyjęte zostały następujące założenie metodologiczne: badaniem zostali objęci rolnicy, którzy prowadzą działalność na terenie omawianego powiatu. Ankietowane były osoby, które formalnie posiadają gospodarstwo, a niekoniecznie prowadzą działalność rolniczą. Respondenci odpowiadali na pytania, wybierając spośród dwóch wariantów „tak” lub „nie”. Badania przeprowadzono w okresie od marca do maja 2013 r. Ankietę wypełniło 94 rolników. Przeprowadzono ją wśród rolników, którzy we wskazanym okresie korzystali z pomocy doradców w Oddziale Dolnośląskiego Ośrodka Doradztwa Rolniczego w Bolesławcu i wyrazili chęć udziału w badaniu, a także podczas bezpośredniego kontaktu $\mathrm{z}$ ankieterem $\mathrm{w}$ domu respondenta.

Pierwsze pytanie zadane respondentom dotyczyło ich stosunku do kwestii zależności rolnictwa od przyrody. Na pytanie „Czy działalność rolnicza zależna jest od przyrody?” odpowiedź twierdzącą dało $93 \%$ ankietowanych. Rolnicy z powiatu bolesławieckiego uważają, że ich działalność w znacznej mierze zależy od sił rządzących przyrodą. Procent pozytywnych odpowiedzi wyglądał inaczej w zależności od wieku pytanego oraz wielkości posiadanego przez niego gospodarstwa. Wszyscy respondenci do 35. roku życia uważają, że działalność rolnicza jest zależna od przyrody. Takiego zadania jest również 92\% rolników w wieku między 35. a 55. rokiem życia oraz niespełna $90 \%$ po 55. roku życia. Te wyniki świadczą o wysokiej świadomości rolników w tej kwestii.

Zauważalna jest jednak zmiana stosunku do zadanego problemu w zależności od wielkości gospodarstwa rolnego. Właściciele gospodarstw większych niż 100 ha są w $100 \%$ przekonani co do tego, że zadowalający wynik ich działalności zależy od przyrody. Taką opinię potwierdza także $87 \%$ posiadaczy mniej niż 5 ha użytków rolnych. 
Barbara Panciszko

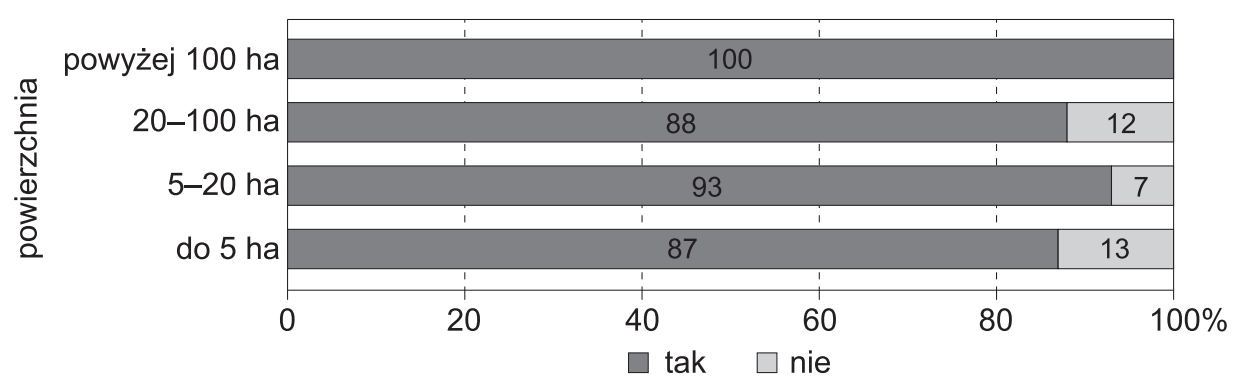

Wykres 2. Stosunek respondentów do kwestii zależności rolnictwa od przyrody w zależności od wielkości posiadanego gospodarstwa

Źródło: opracowanie własne.

Ponad 30\% rolników powiatu bolesławieckiego twierdzi, że rolnictwo nie powoduje zanieczyszczenia środowiska naturalnego.

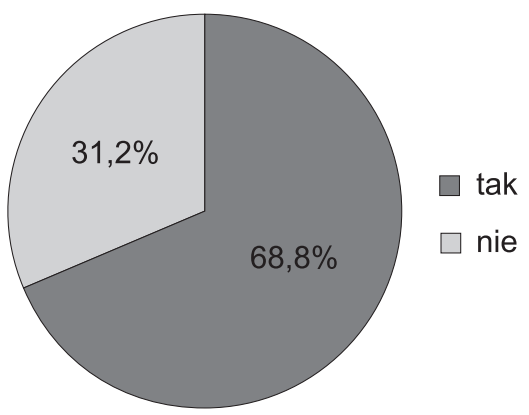

Wykres 3. Rozkład odpowiedzi na pytanie „Czy rolnictwo powoduje zanieczyszczenie środowiska naturalnego?"

Źródło: opracowanie własne.

Zanotowano znaczne różnice w postawach odnośnie do wskazanej kwestii w poszczególnych kategoriach wiekowych. Wyraźnie widać, że młodzi rolnicy mają większą świadomość. Prawie 86\% respondentów w wieku do 35. roku życia uważa, że rolnictwo ma negatywny wpływ na środowisko. Ale już tylko $42 \%$ rolników powyżej 55. roku życia podziela taką opinię.

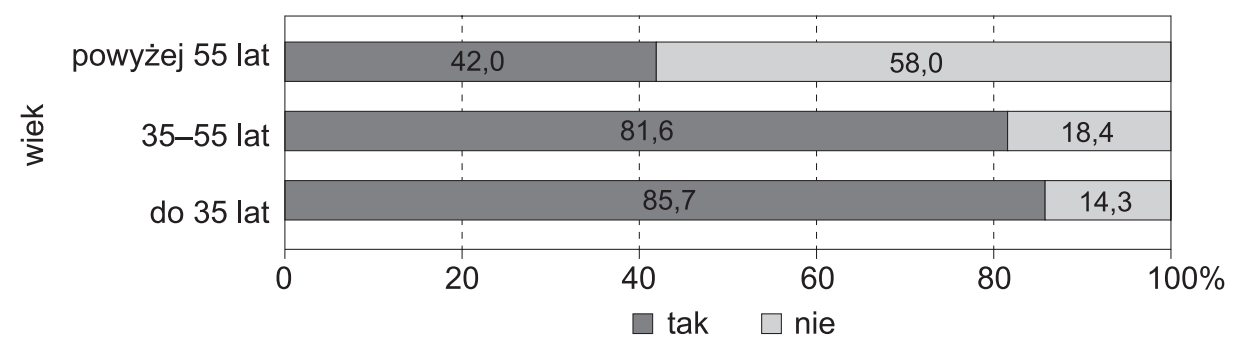

Wykres 4. Rozkład odpowiedzi na pytanie „Czy rolnictwo powoduje zanieczyszczenie środowiska naturalnego?"

Źródło: opracowanie własne. 
Z podobnymi rozbieżnościami mamy do czynienia, gdy weźmiemy pod uwagę wielkość posiadanego areału. Im mniejsze gospodarstwo, tym mniejsza świadomość negatywnego oddziaływania rolnictwa na środowisko. Może wynikać to z tego, że rolnicy posiadający nie więcej niż 5 ha produkują głównie na własne potrzeby. Sądzą więc, że nie ingerują w znaczący sposób w środowisko. Natomiast im większe gospodarstwo, tym wpływ ten jest częściej dostrzegany przez ankietowanych rolników. Niemal $80 \%$ posiadaczy gospodarstw liczących 20 ha i więcej uważa, że rolnictwo niszczy przyrodę. Autorka przypuszcza, że udzielili takiej odpowiedzi, ponieważ stosują większą ilość środków ochrony roślin, pestycydów oraz na szeroką skalę wykorzystują mechanizację.

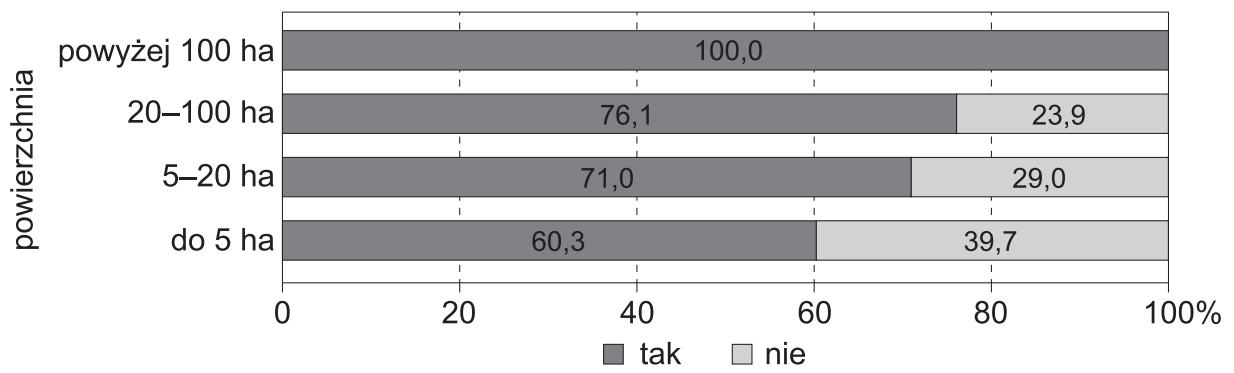

Wykres 5. Rozkład odpowiedzi na pytanie „Czy rolnictwo powoduje zanieczyszczenie środowiska naturalnego?"

Źródło: opracowanie własne.

Następną interesującą autorkę kwestią było poczucie odpowiedzialności rolników za stan środowiska przyrodniczego. Ponad $76 \%$ producentów rolnych z powiatu bolesławieckim czuje się odpowiedzialna za jego stan. Niemniej jednak, podobnie jak w wypadku poprzednich analizowanych odpowiedzi, widać tu pewne różnice w opiniach. $92 \%$ młodych rolników udzieliło odpowiedzi twierdzącej. Co czwarty respondent $\mathrm{w}$ wieku powyżej 35 lat nie zgodził się ze stwierdzeniem zawartym w pytaniu. Największe poczucie odpowiedzialności za stan środowiska mają osoby posiadające gospodarstwo wielkości od 5 do 20 ha ziemi. Pozostali rolnicy w mniejszym stopniu podzielają takie zdanie.

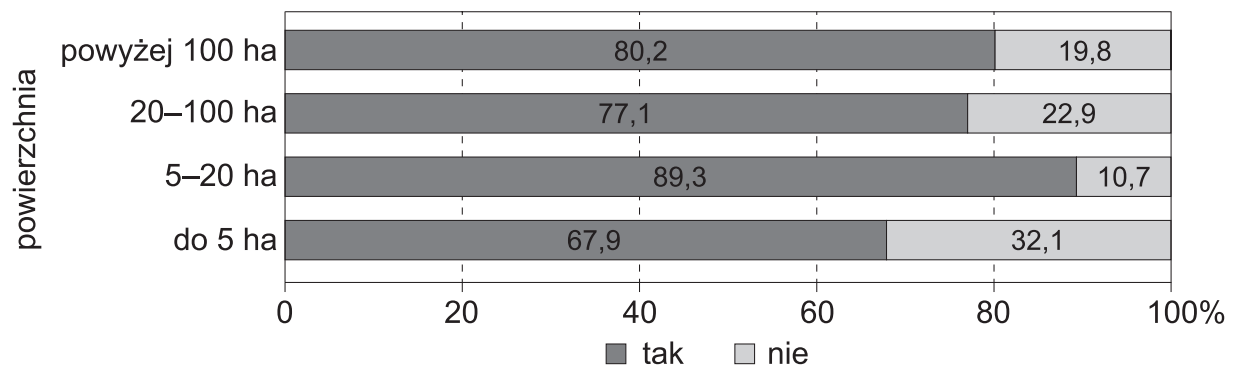

Wykres 6: Rozkład odpowiedzi na pytanie „Czy rolnik jest odpowiedzialny za stan środowiska naturalnego?"

Źródło: opracowanie własne. 
Rolnicy z powiatu bolesławieckiego zgodnie twierdzą, że powinni podejmować działania mające pozytywny wpływ na środowiska, mimo że nie wszyscy rolnicy podzielają zdanie o negatywnym wpływie rolnictwa na środowisko oraz nie czują się odpowiedzialni za jego stan. Zaledwie 7\% respondentów uważa, że nie powinni podejmować takich czynności.

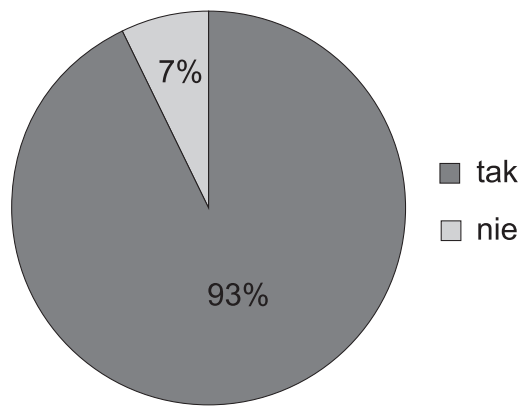

Wykres 7. Rozkład odpowiedzi na pytanie „Czy rolnik powinien podejmować działania, które będą miały pozytywny wpływ na środowisko?"

Źródło: opracowanie własne.

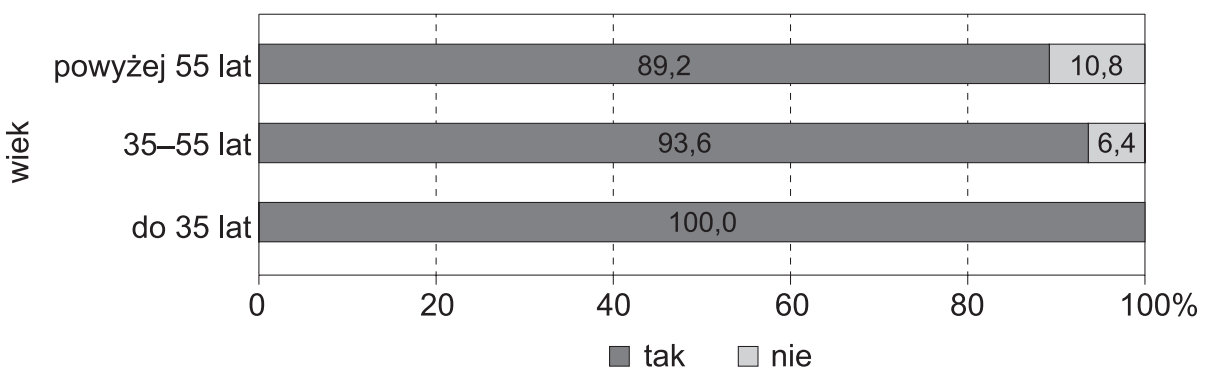

Wykres 8. Rozkład odpowiedzi na pytanie „Czy rolnik powinien podejmować działania, które będą miały pozytywny wpływ na środowisko?"

Źródło: opracowanie własne.

$\mathrm{Z}$ analizy wykresu wynika, że im respondenci są starsi, tym mniejszą widzą potrzebę pracy na rzecz środowiska. Można zatem zaobserwować zmiany mentalne zachodzące u młodego pokolenia. Większy poziom edukacji w tym zakresie sprawia, że osoby poniżej 35. roku życia dysponują większą wiedzą na temat konsekwencji dla środowiska, jakie rodzi nieodpowiednie gospodarowanie, i dlatego dostrzegają konieczność takich działań.

$\mathrm{Z}$ omówionym problemem koresponduje następna kwestia poruszona $\mathrm{w}$ ankiecie. Rolników zapytano „Czy na terenie swojego gospodarstwa wykonuje Pan/ Pani działania na rzecz środowiska?”. Odpowiedzi twierdzącej udzieliło 93\% respondentów. Co ciekawe, uważa tak $91 \%$ posiadaczy nie więcej niż 5 ha, ale za to niemal wszyscy gospodarujący na większym areale. Należy w tym miejscu tak- 
że dodać, że Unia Europejska stawia rolnikom wiele wymogów środowiskowych, które muszą spełnić, aby otrzymać płatność (cross-compliance ${ }^{11}$. Być może osoby posiadające znaczny areał ponoszą większe nakłady dodatkowej pracy i kosztów, dlatego uważają, iż realizują działania na rzecz środowiska. Należy także dodać, że obecnie znaczna część gruntów znajduje się w posiadaniu nielicznej grupy, w związku z czym dochodzi do komasacji gruntów. Jeśli w obrębie tych największych gospodarstw rolnych będzie prowadzona polityka sprzyjająca środowisku, to korzyść dla niego jako całości wydaje się większa. Co prawda, takie czynności podejmują częściej młodsi rolnicy, ale nie ma w tej kwestii znacznych rozbieżności. W granicach 93-95\% rolników do 55. roku życia deklaruje taką działalność.

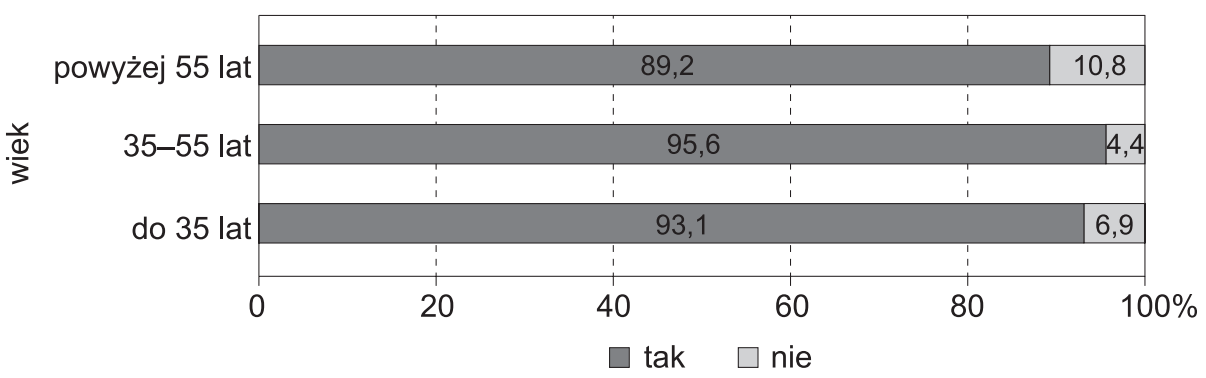

Wykres 9. Rozkład odpowiedzi na pytanie „Czy na terenie swojego gospodarstwa wykonuje Pan/Pani działania na rzecz środowiska?”

Źródło: opracowanie własne.

W kolejnym punkcie autorka zapytała rolników, czy ich zdaniem powinni otrzymywać wynagrodzenie za pracę na rzecz środowiska. Jest to kwestia w znacznej mierze sporna. W zasadzie utrzymanie gospodarstwa $\mathrm{w}$ dobrej kulturze rolnej jest obowiązkiem rolnika. Jak w każdej działalności gospodarczej, należy poczynić pewne nakłady, aby wygenerować zyski. W innych gałęziach również ustala się normy środowiskowe, które przedsiębiorcy muszą spełniać. Jednak rolnictwo jest sektorem wrażliwym. Dlatego - zgodne z założeniami koncepcji wielofunkcyjnego rolnictwa, do którego działania Unii Europejskiej niewątpliwie zmierzają - za pracę dodatkową, przynoszącą korzyści całemu społeczeństwu powinno się przyznawać dodatkowe wynagrodzenie, niemniej jednak tylko w sytuacji, gdy instytucje publiczne uczynią rolnika swego rodzaju „stróżem środowiska przyrodniczego"12.

W powiecie bolesławieckim $63 \%$ rolników chce otrzymywać środki publiczne za działania na rzecz środowiska. Trudno się takim odpowiedziom dziwić, można bowiem przyjąć, że wyniki takiego badania przeprowadzonego wśród innych grup zawodowych byłyby podobne. W społeczeństwie dominuje bowiem przeświadczenie: „skoro mam wykonać jakąś pracę, to powinienem otrzymać za to zapła-

11 Agencja Restrukturyzacji i Modernizacji Rolnictwa, Zasada wzajemnej zgodności, Warszawa 2010.

12 Wspólna Polityka Rolna. Tradycja i nowoczesność, red. M. Szewczyk, R. Sura, Lublin 2007, s. 68. 
tę". Ale rolnik, będąc zależy od tego, co daje natura, powinien pewne czynności wykonywać nieodpłatnie. Jest to bowiem element prawidłowego gospodarowania. Należy jednak wyjaśnić czytelnikowi, co oznacza „prawidłowe gospodarowanie”. Mianowicie, należy do tej kategorii: utrzymywanie czystości i porządku w obrębie gospodarstwa, regularne koszenie, sadzenie żywopłotów, zalesianie nieużytków, a także odpowiednie zabezpieczanie obornika czy osadów ściekowych.

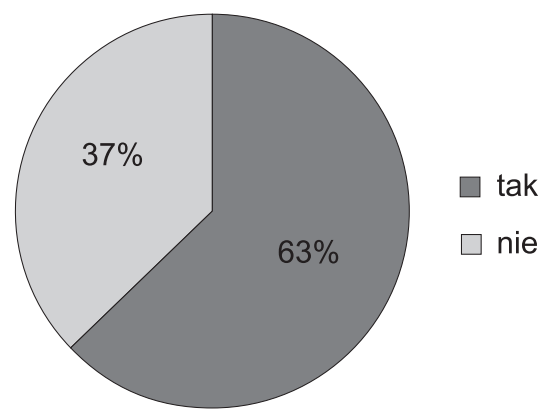

Wykres 10. Rozkład odpowiedzi na pytanie „Czy rolnik powinien otrzymywać wynagrodzenie za pracę na rzecz środowiska?”

Źródło: opracowanie własne.

Interesujące dane prezentuje wykres 11 . Tylko $26 \%$ rolników w wieku do 35 . roku życia uważa, że powinni otrzymywać dodatkowe fundusze za takie prace. Ale domaga się tego już $71 \%$ rolników w wieku powyżej 55 lat. Wniosek z tego płynący jest analogiczny do wyciągniętych w wypadku poprzednich analizowanych problemów - młodzi rolnicy cechują się większą świadomością i są w stanie wykonywać dodatkową pracę na rzecz środowiska nieodpłatnie. Niemniej jednak, rolnicy posiadający gospodarstwo o powierzchni powyżej 100 ha niezależnie od wieku twierdzą, że takie wynagrodzenie powinni otrzymywać. Twierdzi tak również $65 \%$ osób posiadających mniej niż 1 ha. Natomiast tylko 45\% rolników gospodarujących na obszarze od 5 do 20 ha sądzi, że takie płatności są zasadne.

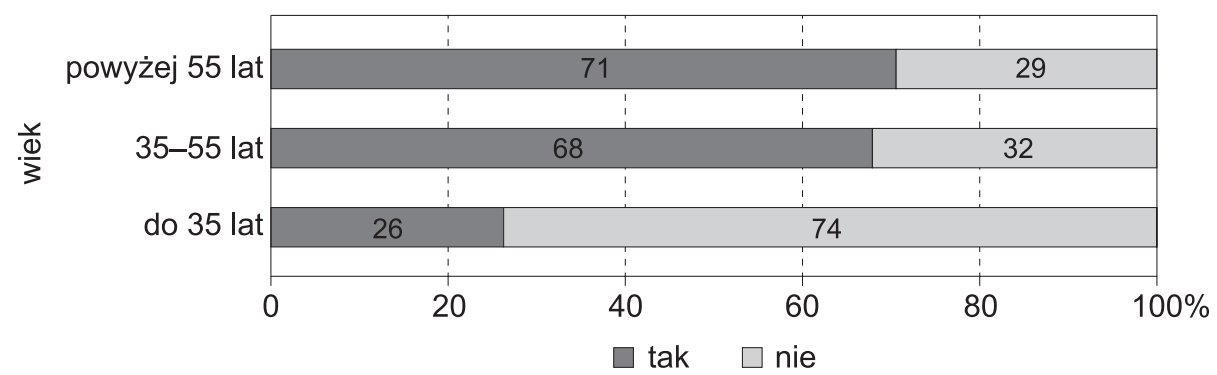

Wykres 11. Rozkład odpowiedzi na pytanie „Czy rolnik powinien otrzymywać wynagrodzenie za pracę na rzecz środowiska?"

Źródło: opracowanie własne. 
Po prezentacji postaw rolników z powiatu bolesławieckiego względem kwestii środowiskowych można przejść do aspektu wykorzystywania środków pochodzących z funduszy Unii Europejskiej na działania przyczyniające się do poprawy stanu środowiska przyrodniczego na analizowanym obszarze. Wyniki ankiety pokazują, że niespełna $30 \%$ respondentów skorzystało z takiej formy wsparcia w roku 2013. Wśród nich największą grupę stanowili ci, którzy pobierali dopłaty do obszarów o niekorzystnych warunkach gospodarowania (53\%); najmniejszą popularnością cieszy się program rolnośrodowiskowy (26\%). Należy również zaznaczyć, że rolnicy niejednokrotnie decydują się na realizację więcej niż jednego działania - czyni tak ok. 20\% badanych. Kolejny aspekt stanowi to, kto najczęściej korzysta $\mathrm{z}$ takich możliwości. Przeważnie są to osoby młode oraz rolnicy gospodarujący na powyżej 100 ha, choć w wypadku tych ostatnich najczęściej wynika to z posiadania pól uprawnych w różnych rejonach i korzystania ze wsparcia na rzecz gospodarowania na obszarach o niekorzystnych warunkach.

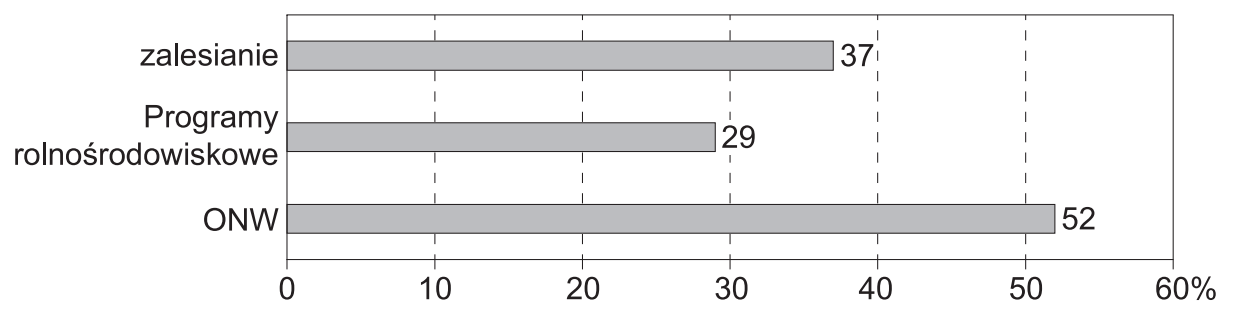

Wykres 12. Działania podejmowane przez rolników powiatu bolesławieckiego na rzecz środowiska naturalnego, współfinansowane przez UE

Źródło: opracowanie własne.

\section{Wnioski}

Tereny powiatu bolesławieckiego charakteryzują się wysokimi walorami przyrodniczymi, których utrzymanie i zachowanie w aktualnym stanie jest uzależnione od działań podejmowanych na rzecz środowiska. Znaczna część tych obszarów położona jest na terenach wykorzystywanych rolniczo. Od zachowania i postaw posiadaczy, zwłaszcza drobnych, gospodarstw rolnych zależy ich przyszłość.

Z analizy przeprowadzonej ankiet wynika, że - ogólnie rzecz biorąc - rolnicy z powiatu bolesławieckiego zgadzają się ze stwierdzeniem o zależności ich działalności od przyrody. Niemal 70\% zdaje sobie sprawę, że ich działalność ma negatywny wpływ na środowisko i dlatego trzy czwarte z nich czują się odpowiedzialne za jego stan. Rolnicy widzą konieczność podejmowania działań mających przyczynić się do poprawy stanu środowiska przyrodniczego, a w swoich gospodarstwach czyni to ponad $93 \%$. Jednocześnie ponad połowa twierdzi, że powinni otrzymywać za to wynagrodzenie. Niestety tylko niespełna $30 \%$ respondentów korzysta z pomocy Unii Europejskiej na realizację takich przedsięwzięć (gospodarowanie na 
ONW, zalesianie, programy rolnośrodowiskowe). Jest to zastanawiające, ponieważ mając możliwość otrzymywania płatności, których niejednokrotnie się domagają, nie potrafią z nich skorzystać. Należy także podkreślić, że najczęściej realizowane działanie - gospodarowanie na obszarach o niekorzystnych warunkach - nie wymaga od rolnika tak dużego zaangażowania zasobów w postaci świadczonej pracy, środków finansowych oraz wiedzy, jak choćby realizacja pakietów programów rolnośrodowiskowych.

W zaprezentowanych wynikach badań widać pewne zmiany pokoleniowe dotyczące sposobu myślenia i postrzegania spraw środowiskowych przez rolników. Młodzi rolnicy (do 35. roku życia) mają większą świadomość tego, że rolnictwo przyczynia się do zanieczyszczania środowiska przyrodniczego, oraz widzą konieczność podejmowania pozytywnych działań na jego rzecz. Zauważalna jest także korelacja poczucia odpowiedzialności rolnika za środowisko naturalne z podejmowaniem takich czynności na terenie jego gospodarstwa. Warto również podkreślić, że młodzi rolnicy w większości nie oczekują za to wynagrodzenia od władz publicznych.

Badania napawają optymizmem na przyszłość. Niestety nie przekłada się to jeszcze na konkretne działania.

\section{Bibliografia}

Agencja Restrukturyzacji i Modernizacji Rolnictwa, Zasada wzajemnej zgodności, Warszawa 2010. Bank Danych Lokalnych, https://bdl.stat.gov.pl/BDL/dane/teryt/tablica.

Działania Wspólnoty Europejskiej na rzecz zrównoważonego rozwoju obszarów wiejskich $w$ Polsce (PROW 2004-2006), red. S. Twardy, Falenty 2006.

Główny Urząd Statystyczny, Charakterystyka gospodarstw rolnych w województwie dolnośląsim Powszechny Spis Rolny 2010, Warszawa 2012.

Karkonoska Agencja Rozwoju Regionalnego S.A., Koncepcja subregionalnego produktu turystycznego Borów Dolnośląskich, Jelenia Góra 2009.

Kucharska A., Przewodnik po programie rolnośrodowiskowym, Warszawa 2009.

Mapa gmin i opis powiatu, 1 marca 2012, http://powiatboleslawiecki.pl/gmina.html.

Rola środków Unii Europejskiej w rozwoju obszarów wiejskich, red. E. Kacprzak, A. Kołodziejczyk, Warszawa 2010.

Rowiński J., PROW 2007-2013. Analiza zatwierdzonej wersji programu i pierwszych lat realizacji, Warszawa 2008.

Rozporządzenie Rady Ministrów z dnia 20 lipca 2004 r. w sprawie szczegółowych warunków i trybu udzielania pomocy finansowej na wsparcie przedsięwzięć rolnośrodowiskowych i poprawy dobrostanu zwierząt objętej planem rozwoju obszarów wiejskich (Dz.U. z 2004 r. Nr 174, poz. 1809).

Rozporządzenie Ministra Rolnictwa i Rozwoju Wsi z dnia 6 maja 2010 r. zmieniające rozporządzenie w sprawie szczegółowych warunków i trybu przyznawania pomocy finansowej w ramach działania „Program rolnośrodowiskowy” objętego Programem Rozwoju Obszarów Wiejskich na lata 2007-2013 (Dz.U. z 2010 r. Nr 76, poz. 500).

Statystyczne Vademecum Samorzadowca, 2017, http://www.stat.gov.pl/vademecum/vademecum_dolnoslaskie/portrety_powiatow/powiat_boleslawiecki.pdf.

Szumski S., Wspólna Polityka Rolna Unii Europejskiej, Warszawa 2007.

Wspólna Polityka Rolna. Tradycja i nowoczesność, red. M. Szewczyk, R. Sura, Lublin 2007. 


\section{Załącznik 1}

\section{ANKIETA}

Nazywam się Barbara Panciszko. Jestem studentką Uniwersytetu Wrocławskiego, Katedry Studiów Europejskich. Piszę pracę magisterską na temat Program rolnośrodowiskowy jako działanie przyczyniajace się do poprawy stanu środowiska naturalnego na obszarach wiejskich powiatu bolesławieckiego.

Celem poniższej ankiety jest zbadanie opinii rolników z powiatu bolesławieckiego na temat odpowiedzialności rolników oraz konieczności podejmowania przez nich działań na rzecz środowiska przyrodniczego.

Poniższa ankieta jest ANONIMOWA. Uprzejmie proszę o szczere odpowiedzi, które posłużą do moich badań.

Proszę odpowiedzieć na poniższe pytania, zaznaczając odpowiedź symbolem „X”

\begin{tabular}{|c|c|c|c|}
\hline & Pytanie & tak & nie \\
\hline 1. & Czy działalność rolnicza jest zależna od przyrody? & & \\
\hline 2. & Czy rolnictwo powoduje zanieczyszczenie środowiska naturalnego? & & \\
\hline 3. & Czy rolnik jest odpowiedzialny za stan środowiska naturalnego? & & \\
\hline 4. & $\begin{array}{l}\text { Czy rolnik powinien podejmować działania, które będą miały pozytywny } \\
\text { wpływ na środowisko (np. regularne koszenie, utrzymanie porządku, zale- } \\
\text { sianie, sadzenie żywopłotów)? }\end{array}$ & & \\
\hline 5. & $\begin{array}{l}\text { Czy na terenie swojego gospodarstwa wykonuje Pan/Pani podane wyżej } \\
\text { (lub inne) działania na rzecz środowiska? }\end{array}$ & & \\
\hline 6. & $\begin{array}{l}\text { Czy rolnik powinien otrzymywać wynagrodzenie za pracę na rzecz środo- } \\
\text { wiska naturalnego? }\end{array}$ & & \\
\hline 7. & $\begin{array}{l}\text { Czy korzystał(-a) Pan/Pani z pomocy Unii Europejskiej na działania zwią- } \\
\text { zane z ochroną środowiska? (Jeżeli tak, to proszę odpowiedzieć na poniższe } \\
\text { pytania.) }\end{array}$ & & \\
\hline 8. & Czy Pan/Pani zalesiała? & & \\
\hline 9. & Czy Pan/Pani realizuje program rolnośrodowiskowy? & & \\
\hline 10. & $\begin{array}{l}\text { Czy otrzymuje Pan/Pani dopłaty do obszarów o niekorzystnych warunkach } \\
\text { gospodarowania (ONW)? }\end{array}$ & & \\
\hline
\end{tabular}

\section{Metryczka}

\begin{tabular}{|c|c|c|c|}
\hline \multirow{4}{*}{ Wiek } & Do 35 lat & \multirow{4}{*}{$\begin{array}{l}\text { Powierzchnia } \\
\text { gospodarstwa }\end{array}$} & Do 5 ha \\
\hline & \multirow{2}{*}{$\begin{array}{c}\text { Między } 35 . \text { a } 55 . \text { rokiem } \\
\text { życia }\end{array}$} & & Między 5 a 20 ha \\
\hline & & & Między 20 a 100 ha \\
\hline & Powyżej 55 lat & & Powyżej 100 ha \\
\hline
\end{tabular}

Dziękuję bardzo! 